\title{
РАЗРАБОТКА РЕЦЕПТУР ХЛЕБА С ДОБАВЛЕНИЕМ МУКИ ИЗ ЗЕРНА ЯЧМЕНЯ И ТРИТИКАЛЕ
}

\author{
Yu.A. Letyago, R.I. Belkina
}

\section{THE DEVELOPMENT OF BREAD RECIPES WITH THE ADDITION OF THE FLOUR FROM BARLEY AND TRITICALE GRAIN}

Летяго Ю.А. - канд. с.-х. наук, доц. каф. технологий продуктов питания Государственного аграрного университета Северного Зауралья, г. Тюмень. E-mail: 77720143684@mail.ru

Белкина Р.И. - д-р с.-х. наук, профр. каф. технологий производства, хранения и переработки продукции растениеводства Государственного аграрного университета Северного Зауралья, г. Тюмень. E-mail: raisa-medvedko@mail.ru

Разработка рецептур хлебобулочных изделий с применением натуральных компонентов для обогащения их витаминами, микроэлементами и другими полезными веществами одно из важнейших направлений исследований. В связи с этим определенный интерес представляют разработки технологий и рещептур, связанных с использованием пищевых обогатителей, в том числе нетрадиционного для хлебопечения сырья. Цель исследований разработка новых рецептур хлеба с использованием в смесях с пшеничной мукой муки голозерного ячменя и муки тритикале. Исследования проведены в Агробиотехнологическом центре Государственного аграрного универcumema Северного Зауралья, г. Тюмень, Тюменская область. В качестве натуральных обогатителей пшеничной муки использована обойная мука из пигментированного голозерного ячменя сорта Гранал 32, обладающего повышенной антиоксидантной активностью, и обойная мука из высокобелкового голозерного ячменя сорта Нудум 95 и зерна тритикале Цекад 90. Смеси муки оценивали по следующим показателям: содержание клейковины, качество клейковины, число падения, содержание белка, сила муки. Определены органолептические и физико-химические показатели качества готовой продукции в соответствии с требованиями государственного стандарта. $B$ ре-
Letyago Yu.A. - Cand. Agr. Sci., Assoc. Prof., Chair of Food Technologies, Northern Trans-Urals State Agrarian University, Tyumen.

E-mail: 77720143684@mail.ru

Belkina R.I. - Dr. Agr. Sci., Prof., Chair of Production Technologies, Storage and Processing of Production of Plant Growing, Northern Trans-Urals State Agrarian University, Tyumen.

E-mail: raisa-medvedko@mail.ru

зультате эксперимента выявлены оптимальные варианты смесей, включающие соотношения: пшеничная мука и мука из зерна голозерного пигментированного ячменя сорта Гранал 32 (90+10\%), хлеб получил название «Гранал»; пшеничная мука, мука из зерна голозерного ячменя сорта Нудум 95 и мука из зерна тритикале сорта Цекад 90 (70+10+20\%), хлеб получил название «Ясень». Разработанные рецептуры хлеба подтверждены патентами: № 2640348 «Способ производства хлеба»; № 2634484 «Способ производства хлеба «Ясень»».

Ключевые слова: новые рецептуры хлеба, клейковина, содержание белка, сила муки, объем хлеба, общая оценка хлеба, влажность, кислотность хлеба.

The development of bakery product formulations using natural ingredients to enrich them with vitamins, trace elements and other beneficial substances is one of the most important areas of the research. In this regard, the development of technologies and formulations related to the use of food fortifiers, including non-traditional raw materials for baking, are of particular interest. The purpose of the research is the development of new bread formulations using in mixtures with wheat flour, hullless barley flour and triticale flour. The studies were conducted at the Agrobiotechnological Center of 
the State Agrarian University of the Northern TransUrals, Tyumen, Tyumen Region. As a natural enrichment agent for wheat flour, wallpaper flour made from pigmented hull-less barley of Granal 32 variety having an increased antioxidant activity was used, and wallpaper from high-protein hull-less barley of Nudum 95 variety and triticale grain Tsekad 90. The flour mixtures were evaluated by the following indicators: gluten content, gluten quality, the number drops, protein content and flour strength. Organoleptic and physical and chemical indicators of the quality of finished products were determined in accordance with the requirements of the state standard. As a result of the experiment, the optimal mixes were revealed, including the following ratios: wheat flour and the flour from the grain of hull-less pigmented barley of Granal 32 variety (90+10\%), the bread was called "Granal"; wheat flour, the flour from the grain of hull-less barley of Nudum 95 variety and the flour from triticale grain of Tsekad 90 variety $(70+10+20 \%)$, the bread was called "Yasen". Developed bread formulations have been confirmed by patents: No. 2640348 "The method for the production of bread"; No. 2634484 "The method for the production of bread "Yasen".

Keywords: new bread recipes, gluten, protein content, flour strength, bread volume, the overall assessment of bread, moisture, bread acidity.

Введение. Обогащение пшеничной муки высших сортов натуральными компонентами с повышенным содержанием витаминов, микроэлементов и других полезных веществ - одна из важнейших задач общей проблемы повышения качества и питательности хлебобулочных изделий. В настоящее время ухудшение качества хлеба связано с использованием в технологиях его приготовления муки общего назначения, различных улучшителей, нетрадиционного сырья, химических веществ и т.п. [1-3].

В связи с этим наиболее ценными для потребителей несомненно будут такие хлебные изделия, в рецептуре которых присутствуют только натуральные компоненты $[4,5]$.

Одним из таких компонентов считается зерно ячменя, которое по содержанию незаменимых аминокислот намного ценнее, чем зерно пшеницы [6]. Особый интерес с точки зрения питательной ценности, содержания белка и незаменимых аминокислот представляют голозерные сорта ячменя. А.А. Грязновым [7] дана сравнительная характеристика сортов пленчатого и голозерного ячменя по содержанию незаменимых аминокислот в зерне. Наиболее высокое значение суммы незаменимых аминокислот в зерне голозерного пигментированного ячменя сорта Гранал 32 - 5,06 \%, в зерне голозерного ячменя сорта Нудум 95 - 4,83 \% и значительно ниже - в зерне пленчатого ячменя сорта Челябинский 99 - 3,96 \%. Автор отмечает, что голозерные сорта ячменя также отличаются высоким содержанием макро- и микроэлементов.

Все большее развитие получает производство хлебобулочных изделий лечебно-профилактического назначения, в частности с антиоксидантными свойствами [8]. Для этих целей в качестве компонента в рецептурах целесообразно использовать зерно голозерного пигментированного ячменя сорта Гранал 32, который отличается повышенным содержанием проантоцианидов (антоцианидинов) - активных биологических антиоксидантов [7] .

Высокой питательной ценностью белка характеризуется зерно тритикале. В частности, содержание незаменимой аминокислоты лизина в зерне этой культуры выше, чем в зерне других зерновых культур [9]. Ценность тритикале в хлебопекарном производстве объясняется тем, что она объединяет высокие хлебопекарные свойства пшеницы и специфические свойства ржи - высокое содержание биологически активных ароматических веществ. Такое сочетание обеспечивает получение ряда диетических продуктов [10].

Цель исследований. Разработка новых рецептур хлеба с использованием в смесях с пшеничной мукой муки голозерного ячменя и муки тритикале.

Методы исследований. Пшеничная мука высшего сорта служила основой для изучения новых рецептур. Как обогатители пшеничной муки использовали обойную муку из зерна ячменя и тритикале. Эту муку получали размолом на лабораторной мельнице ЛМТ-1. Варианты для изучения рецептур с добавкой голозерного пигментированного ячменя Гранал 32 предусматривали включение в смесь с пшеничной мукой 10, 20, 30 и 40 \% муки ячменной. Варианты для изучения рецептур с добавкой голозерного ячменя Нудум 95 и тритикале Цекад 90 
предусматривали включение в смесь с пшеничной мукой соответствующего количества ячменной муки и муки из зерна тритикале: 10 и $20 \%$; 20 и $20 \%$; 30 и $20 \%$; 20 и $30 \%$. По рецептуре, на 100 граммов муки вносили 3,0 г дрожжей, 1,3 г соли, 2,5 г сахара, воды - с учетом водопоглотительной способности муки. Выпекали хлеб безопарным способом без улучшителей в соответствии с методикой Госкомиссии по сортоиспытанию. Оценку качества муки и хлеба проводили согласно методам ГОСТ.

Результаты исследований и их обсуждение. Результаты определения количества и качества клейковины в пшеничной муке и смесях ее с мукой из зерна ячменя сорта Гранал 32 показали, что количество клейковины снижалось по мере увеличения компонента муки из ячменя. Так, процент клейковины в муке пшеницы был на уровне 32, а в смесях с добавлением 10, 20,30 и $40 \%$ ячменной муки составил соответственно 29, 26, 24, и $21 \%$. Качество клейковины пшеничной муки и смесей соответствовало требованиям ГОСТа на муку пшеничную хлебопе- карную (60-68 ед. ИДК) [11]. В вариантах с добавлением 20, 30 и 40 \% ячменной муки клейковина становилась более упругой.

Содержание белка, так же как и содержание клейковины, заметно снижалось в вариантах с долей ячменной муки 30 и $40 \%$, что можно объяснить высоким содержанием компонента обойной муки.

Активность фермента альфра-амилаза, определяемая по числу падения, в пшеничной муке была невысокой - число падения 297 с. Это соответствует нормативам ГОСТа на хлебопекарную муку. Отмечено увеличение величины этого показателя в вариантах с добавлением муки ячменя.

Сила муки соответствовала требованиям к сильной пшенице (не менее 280 е.а.) в двух вариантах: в варианте с пшеничной мукой и в варианте с добавлением $10 \%$ ячменной муки (рис. 1). В остальных вариантах сила муки составила менее 200 е.а., т.е. снизилась значительно.

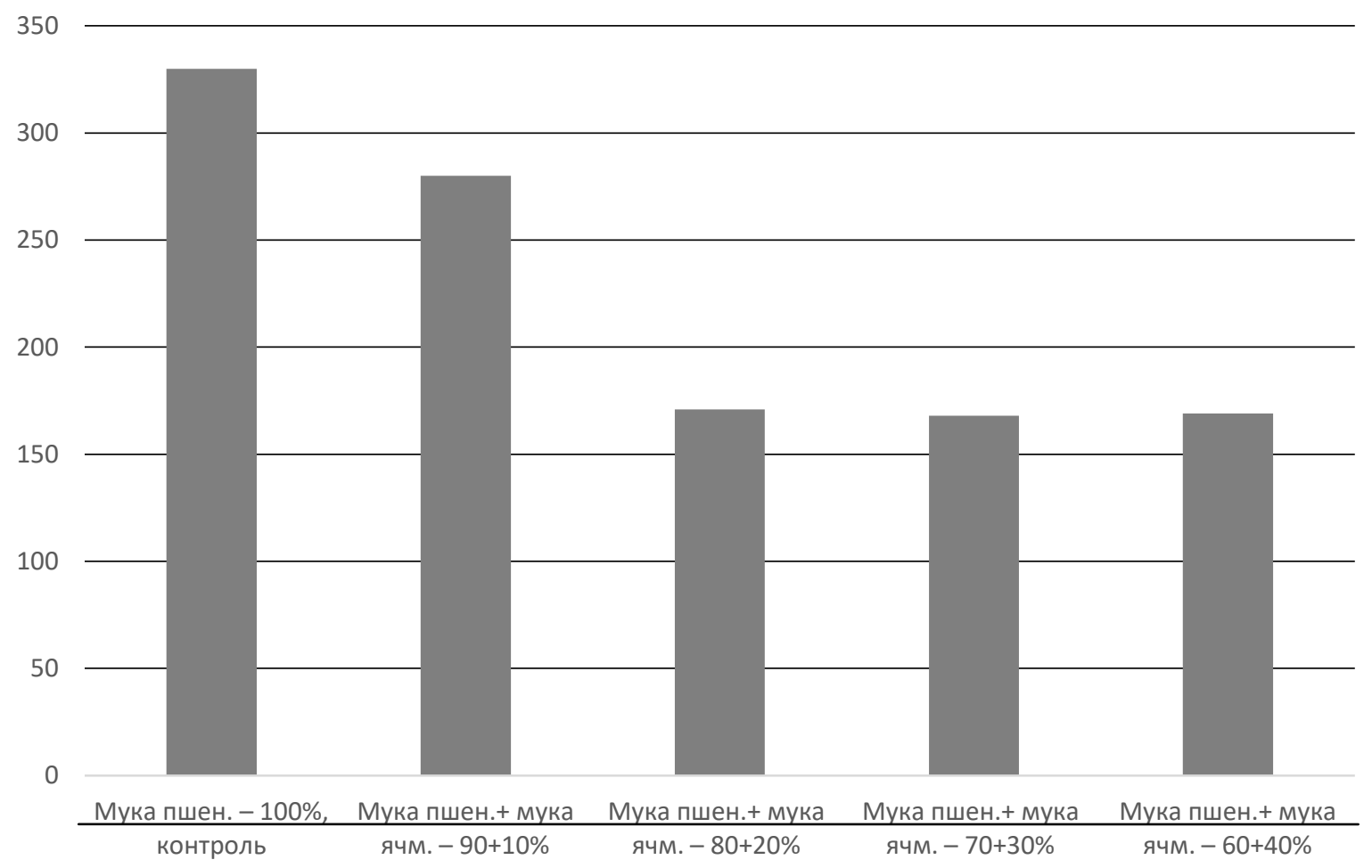

Puc. 1. Сила муки в вариантах с пшеничной мукой и смесями пшеничной и ячменной муки, е.а. 
Объем хлеба из пшеничной муки характеризовался более высокой величиной - $550 \mathrm{~cm}^{3}$ (табл. 1). В вариантах со смесями этот показатель снижался. Наиболее близким к контролю был вариант с добавлением ячменной муки в количестве $10 \%\left(470 \mathrm{~cm}^{3}\right)$. Самое высокое значение общей оценки хлеба отмечено также в контрольном варианте (4,4 балла). В вариантах со смесями снижение относительно контроля составило 0,8-2,3 балла. Из изучаемых вариантов по общей оценке хлеба выделился вариант с добавлением ячменной муки в количестве $10 \%$ (3,6 балла).

\section{Объем и общая оценка хлеба из смесей пшеничной и ячменной муки}

\begin{tabular}{|l|c|c|}
\hline \multicolumn{1}{|c|}{ Образец } & $\begin{array}{c}\text { Объем хлеба, см³/100 г } \\
\text { муки }\end{array}$ & $\begin{array}{c}\text { Общая оценка хлеба, } \\
\text { балл }\end{array}$ \\
\hline Мука пшен. - 100 \%, контроль & $550 \pm 22$ & $4,4 \pm 0,2$ \\
\hline Мука пшен.+ мука ячм. $-90+10 \%$ & $470 \pm 15$ & $3,6 \pm 0,2$ \\
\hline Мука пшен.+ мука ячм. $-80+20 \%$ & $457 \pm 12$ & $3,3 \pm 0,1$ \\
\hline Мука пшен.+ мука ячм. $-70+30 \%$ & $419 \pm 14$ & $3,1 \pm 0,1$ \\
\hline Мука пшен.+ мука ячм. $-60+40 \%$ & $348 \pm 10$ & $2,2 \pm 0,1$ \\
\hline
\end{tabular}

На основании представленных показателей, а также с учетом органолептических показателей качества хлеба из изучаемых вариантов выделился вариант, где использовалась смесь: мука пшеничная + мука ячменная из зерна сорта Гранал 32 в соотношении $90+10 \%$.
Хлеб, выпеченный по этой рецептуре, характеризовался также наиболее близкими показателями к контролю по влажности и кислотности (рис. 2, 3).

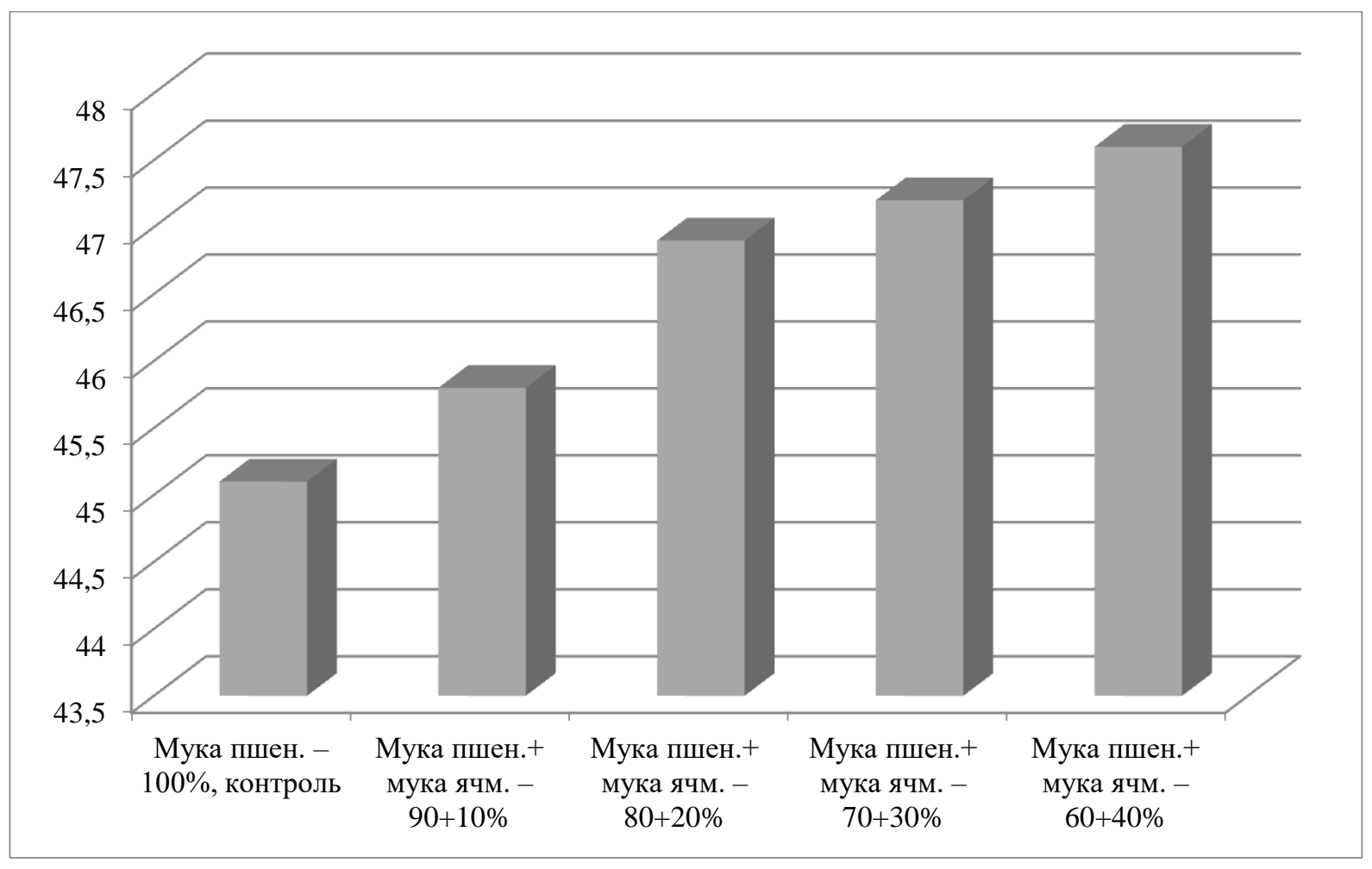

Puc. 2. Влажность хлеба из смесей пшеничной и ячменной муки 


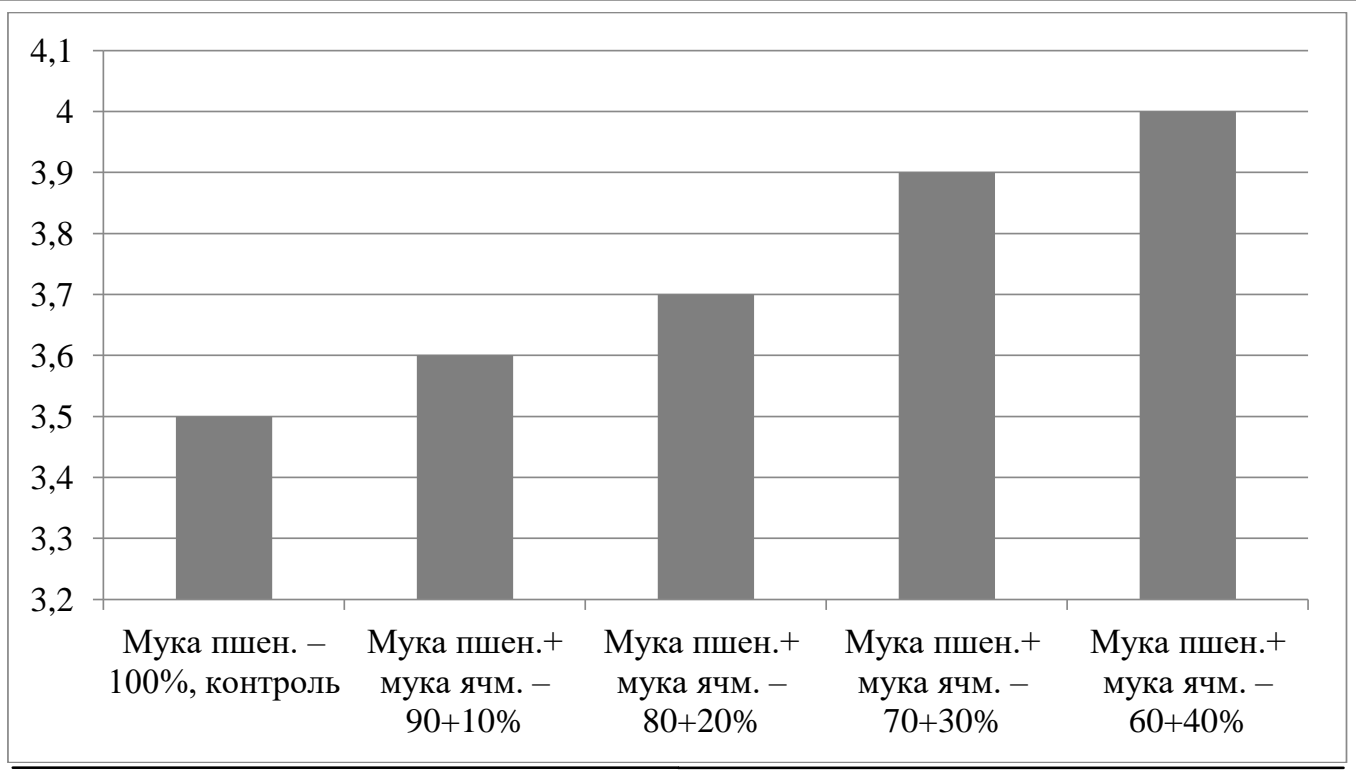

Рис. 3. Кислотность хлеба из смесей пшеничной и ячменной муки

Варианты смесей, представленные пшеничной мукой, мукой из зерна голозерного ячменя Нудум 95 и из зерна тритикале Цекад 90, уступали по содержанию клейковины контролю (табл. 2). Наиболее близкие к контролю значения получены в варианте с соотношением указанных выше видов смесей: $70+10+20 \%(27,0 \%)$.

Таблица 2

\section{Результаты оценки качества смесей пшеничной муки, муки из зерна ячменя и муки из зерна тритикале}

\begin{tabular}{|c|c|c|c|}
\hline \multirow[b]{2}{*}{ Образец } & \multicolumn{2}{|c|}{ Клейковина } & \multirow{2}{*}{$\begin{array}{c}\text { Белок, } \\
\%\end{array}$} \\
\hline & $\%$ & ед. ИДК & \\
\hline Мука пшен. - 100 \%, контроль & 32,1 & 63 & 14,5 \\
\hline Мука пшен.+ мука ячм.+ мука тритик. - 70+10+20 \% & 27,0 & 70 & 14,8 \\
\hline Мука пшен.+ мука ячм.+ мука тритик. $-60+20+20$ \% & 24,1 & 60 & 15,2 \\
\hline Мука пшен.+ мука ячм.+ мука тритик. $-50+30+20$ \% & 22,6 & 65 & 15,6 \\
\hline Мука пшен.+ мука ячм.+ мука тритик. $-60+20+30$ \% & 22,5 & 65 & 14,9 \\
\hline $\mathrm{HCP}_{05}$ & 0,6 & 5 & 1,1 \\
\hline
\end{tabular}

Во всех вариантах качество клейковины соответствовало требованиям ГОСТ 26574-2017 на сортовую муку. С учетом требований стандарта мука варианта смеси $70+10+20$ (мука пшен.+мука ячм.+мука тритик.) соответствует по содержанию и качеству клейковины второму сорту.

По содержанию белка наблюдалась тенденция его увеличения в вариантах со смесями. В варианте, где доля ячменной муки составила $30 \%$, самый высокий показатель (15,6 \%).

По числу падения мука пшеничная и мука смесей соответствовали нормативам ГОСТа на хлебопекарную муку (более 200 с). Снижение величины показателя в вариантах со смесями относительно контроля (на 52-90 с), повидимому, связано с повышенной активностью амилолитических фрерментов в муке тритикале.

Отмечено снижение силы муки в вариантах со смесями. Показатель на контроле составил 330 е.а. - это в пределах нормативов на сильную пшеницу, в последующих вариантах: 209; 215; 145; 250 е.а. Таким образом, самый низкий показатель в варианте, где максимальное количество ячменной муки. В остальных вариантах со смесями сила муки незначительно отличает- 
ся от требований на ценную пшеницу (не менее 260 e.a.).

По результатам органолептической и дегустационной оценок выделился вариант, где доля пшеничной муки составляла $70 \%$, ячменной - $10 \%$ и тритикалевой - $20 \%$, а также с учетом объема хлеба и его общей оценки.

Влажность хлеба в вариантах со смесями находилась почти на одном уровне - 45,245,6 \% и практически не отличалась от влажности хлеба контрольного варианта (45,1\%). Эти показатели - в пределах требований ГОСТа на формовой хлеб из пшеничной муки первого и второго сорта [12].

Кислотность хлеба контрольного варианта составила 3,5 град; в варианте, где доля ячменной муки составляла $30 \%$, тритикалевой $20 \%$, величина данного показателя незначительно увеличивалась и достигла 4,0 град. Эти значения соответствуют требованиям ГОСТа на хлеб из пшеничной муки второго сорта.

Заключение. По результатам исследований выделена и рекомендована производству рецептура, включающая пшеничную муку и муку голозерного пигментированного ячменя сорта Гранал 32 в соотношении $90+10 \%$, а также рецептура, включающая пшеничную муку, муку из зерна голозерного ячменя Нудум 95 и муку из зерна тритикале сорта Цекад 90 в соотношении: $70+10+20 \%$. Эти рецептуры подтверждены патентами $[13,14]$.

\section{Литература}

1. Чубенко Н.Т. Ассортимент хлеба. Оценка, действительность и задачи // Хлебопечение России. - 2013. - № 6. - С. 15-19.

2. Мелешкина E. Нужно ли нам качество зерна? // Хлебопродукты. - 2011. - № 7. C. 10-13.

3. Алехина Н.Н., Пономарева Е.И., Жаркова И.М. [и др.]. Оценка пищевой ценности хлебопекарных смесей и зернового хлеба на их основе // Известия вузов. Пищевая технология. - 2019. - № 1. - С. 10-13.

4. Темникова О.Е., Егориев Н.А., Зимичев А.В. Обзор использования нетрадиционного сырья // Хлебопродукты. - 2012. № 4. - C. 54-55.
5. Темникова О.Е., Шишкина Я.В. Использование ячневой крупы при производстве хлебобулочных изделий // Хлебопродукты. - 2015. - № 12. - С. 57-59.

6. Белкина Р.И., Жукова В.Т. Содержание незаменимых аминокислот в зерне пшеницы, овса, ячменя // Поиск и творчество молодых - реализации продовольственной программы. - Тюмень: НИИСХ Северного Зауралья, 1985. - С. 40.

7. Грязнов А.А. Ячмень голозерный в условиях неустойчивого увлажнения: монография. - Куртамыш: ООО «Куртамышская типографияя», 2014. - 300 c.

8. Косован А.П. Научное обеспечение хлебопекарной отрасли // Хлебопечение России. - 2013. - № 6. - С. 13-14.

9. Продукты переработки зерна тритикале в технологии хлебобулочных изделий / Л.П. Пащенко [и др.] // Вестник РАСХН. 2003. - № 2. - C. 84-86.

10. Шаболкина Е.Н., Анисимкина Н.М., Беляева M.B. Технологические и хлебопекарные качества тритикале // Зерновое хозяйство России. - 2019. - № 2(62). - С. 21-26.

11. ГОСТ 26574-2017. Мука пшеничная хлебопекарная. Технические условия. - М.: Стандартинформ, 2017. - 12 с.

12. ГОСТ 26987-86. Хлеб белый из пшеничной муки высшего, первого и второго сортов. Технические условия. - М.: Изд-во стандартов, 2002. $-11 \mathrm{C}$.

13. Пат. № 2640348 Российская Федерация. Способ производства хлеба / Грязнов А.А., Летяго Ю.А., Белкина Р.И., Пономарева Е.И. - Госреестр изобретений РФ 27 декабря 2017 г.

14. Пат. № 2634484 Способ производства хлеба «Ясень» / Грязнов А.А., Летяго Ю.А., Белкина Р.И., Пономарева Е.И. Госреестр изобретений РФ 31 октября 2017 г.

\section{Literatura}

1. Chubenko N.T. Assortiment hleba. Ocenka, dejstvitel'nost' i zadachi // Hlebopechenie Rossii. - 2013. - № 6. - S. 15-19. 
2. Meleshkina E. Nuzhno li nam kachestvo zerna? // Hleboprodukty. - 2011. - № 7. S. 10-13.

3. Alehina N.N., Ponomareva E.I., Zharkova I.M. [i dr.]. Ocenka pishhevoj cennosti hlebopekarnyh smesej i zernovogo hleba na ih osnove // Izvestija vuzov. Pishhevaja tehnologija. 2019. - № 1. - S. 10-13.

4. Temnikova O.E., Egorcev N.A., Zimichev A.V. Obzor ispol'zovanija netradicionnogo syr'ja // Hleboprodukty. - 2012. - № 4. - S. 54-55.

5. Temnikova O.E., Shishkina Ja.V. Ispol'zovanie jachnevoj krupy pri proizvodstve hlebobulochnyh izdelij // Hleboprodukty. - 2015. - № 12. S. 57-59.

6. Belkina R.I., Zhukova V.T. Soderzhanie nezamenimyh aminokislot $v$ zerne pshenicy, ovsa, jachmenja // Poisk i tvorchestvo molodyh - realizacii prodovol'stvennoj programmy. Tjumen': NIISH Severnogo Zaural'ja, 1985. S. 40.

7. Grjaznov A.A. Jachmen' golozernyj v uslovijah neustojchivogo uvlazhnenija: monografija. Kurtamysh: 000 «Kurtamyshskaja tipografija», 2014. $-300 \mathrm{~s}$.
8. Kosovan A.P. Nauchnoe obespechenie hlebopekarnoj otrasli // Hlebopechenie Rossii. 2013. - № 6. - S. 13-14.

9. Produkty pererabotki zerna tritikale $v$ tehnologii hlebobulochnyh izdelij / L.P. Pashhenko [l dr.] // Vestnik RASHN. - 2003. - № 2. S. 84-86.

10. Shabolkina E.N., Anisimkina N.M., Beljaeva M.V. Tehnologicheskie i hlebopekarnye kachestva tritikale // Zernovoe hozjajstvo Rossii. - 2019. - № 2(62). - S. 21-26.

11. GOST 26574-2017. Muka pshenichnaja hlebopekarnaja. Tehnicheskie uslovija. - M.: Standartinform, 2017. - $12 \mathrm{~s}$.

12. GOST 26987-86. Hleb belyj iz pshenichnoj muki vysshego, pervogo i vtorogo sortov. Tehnicheskie uslovija. - M.: Izd-vo standartov, 2002. - $11 \mathrm{~s}$

13. Pat. № 2640348 Rossijskaja Federacija. Sposob proizvodstva hleba / Griaznov A.A., Letjago Ju.A., Belkina R.I., Ponomareva E.I. Gosreestr izobretenij RF 27 dekabrja $2017 \mathrm{~g}$.

14. Pat. № 2634484 Sposob proizvodstva hleba «Jasen'» / Grjaznov A.A., Letjago Ju.A., Belkina R.I., Ponomareva E.I. - Gosreestr izobretenij RF 31 oktjabrja $2017 \mathrm{~g}$. 